\title{
SOLAR-BASED FUZZY INTELLIGENT WATER SPRINKLE SYSTEM
}

\section{SISTEM KECERDASAN FUZZY UNTUK PENYIRAM TANAMAN MENGGUNAKAN TENAGA SURYA}

\author{
Riza Muhida ${ }^{1}$, Momoh Jimoh E. Salami ${ }^{2}$, Winda Astuti ${ }^{2}$, \\ Nurul Amalina Bt Ahmad Kasim², Nani Rahayu ${ }^{2}$ \\ ${ }^{1}$ STKIP Surya, Surya Research and Education Center \\ Scientia Garden, Gading Serpong, Tangerang, \\ Banten 15810, Indonesia \\ ${ }^{2}$ Department of Mechatronics Engineering, Faculty of Engineering \\ International Islamic University Malaysia \\ Jalan Gombak, 53100 Kuala Lumpur, Malaysia \\ muhida@gmail.com
}

Recieved: May $9^{\text {th }}$, 2011; Revised: May 27 ${ }^{\text {th }}$, 2011; Accepted: November $24^{\text {th }}$, 2011; Published online: December $22^{\text {th }}$, 2011.

\begin{abstract}
Abstrak
Sistem kecerdasan fuzzy untuk penyiram tanaman menggunakan tenaga surya sudah dikembangkan untuk meningkatkan keefektifan penyiraman tanaman yaitu dengan membuat sistem ini bekerja secara otomatis. Sistem pengendali terdiri dari suatu sensor kelembaban tanah yang bekerja menggunakan prinsip kapasitansi listrik, yang ditanamkan di dalam tanah. Sensor ini kemudian dihubungkan dengan antarmuka dengan unit pengontrol Motorola 68HC11. Pemograman mikrokontroler berdasarkan aturan pengambilan keputusan melalui pendekatan logika fuzzy. Sistem secara keseluruhan menggunakan tenaga dari energi surya. Sistem ini dihubungkan kepada suatu jenis pewaktu irigasi untuk penjadwalan pemupukan tanaman dan detektor hujan mengunakan pengumpul hujan jenis ember kembar. Unit pengendali untuk membuka katup pengendali irigasi ditempatkan dalam satu garis antara sensor kelembaban tanah dan dua jenis divais lainnya yaitu pewaktu irigasi dan pendeteksi hujan. Unit pengendali ini secara otomatis mengirimkan sinyal stop kepada katup pengendali ketika kondisi rumput basah dan tidak memerlukan irigasi. Menggunakan sistem ini, kami mengkombinasikan penerapan logika di dalam area irigasi dan peralatan sensor cuaca, dan membuat pendistribusian air mejadi lebih efisisen.
\end{abstract}

Kata Kunci: surya, penyiram tanaman, fuzzy, mikrokontroler.

\begin{abstract}
A solar-based intelligent water sprinkler system project that has been developed to ensure the effectiveness in watering the plant is improved by making the system automated. The control system consists of an electricalcapacitance soil moisture sensor installed into the ground which is interfaced to a controller unit of Motorola 68 HC11 Handy board microcontroller. The microcontroller was programmed based on the decision rules made using fuzzy logic approach on when to water the lawn. The whole system is powered up by the solar energy which is then interfaced to a particular type of irrigation timer for plant fertilizing schedule and rain detector through a simple design of rain dual-collector tipping bucket. The controller unit automatically disrupted voltage signals sent to the control valves whenever irrigation was not needed. Using this system we combined the logic implementation in the area of irrigation and weather sensing equipment, and more efficient water delivery can be made possible.
\end{abstract}

Keywords: solar, water sprinkler, fuzzy, microcontroller.

\section{INTRODUCTION}

The primary reason for watering is to provide water to plant when the frequency and amount of rainfall is insufficient to replenish water used by the plant system. Sprinkler watering system is a method of applying water similar to rainfall. However, the extreme use of water will result in ill water distribution and landscapes overirrigating which cause one-third of urban water to be wasted [1]. Keeping these facts in mind, we decided to tackle part of the problem by trying to improve the water efficiency in irrigation systems by proposing an intelligent water sprinkler that can be operated automatically based on the moisture level of the soil using soil moisture sensor placed in the soil. A microcontroller activates a valve when signal from the sensor indicates the moisture level of the soil is low or not enough. Based on that, water is distributed through a pipe to be sprayed into the air covering entire soil surface through spray heads so that it breaks up into water drops and fall to the ground. 
This solar-based intelligent water sprinkler system is not like other ordinary water sprinkler. The conventional watering system is operated manually and using common electrical power supply source. This water sprinkler is a solarbased intelligent water sprinkler, which is designed to operate automatically, manages water correctly based on the type of soil and keeps the plant healthy by watering the plant at the right time and also not over waterring the plant.

This water sprinkler system is a closed loop system. Figure 1 shows the block diagram of the solar-based intelligent water sprinkler system. The soil moisture sensor senses condition of moisture in the soil for the grass or plant [1-18]. Then the signal or information from the sensor will be sent to microcontroller (M68HC11) which acts as the brain of the whole system. In order to create the ability of the intelligent system to automate the irrigation process, fuzzy logic system approach is implemented for the brain of the controller. The output signal from the sensor is in the form of voltage. Beside the information about soil moisture, the microcontroller will also check weather condition and fertilizing needs of the plants. Then the controller decides the next operation or task, wether to activate the valve and sprinkler or not.

Another advantage of this system is that alternative power used as a power supply for the system is photovoltaic. The power from the PV system is needed to power up the microcontroller, sensors and valve. The solar system is chosen for the system because its energy from the sun is not only free but also environmentally friendly to the system and accomplishes the task of keeping healthy growth of plant. The main objective of this research is to design and develop a solarbased intelligent water sprinkler system that is capable of monitoring and adjusting its environment accordingly by using soil moisture sensor and powered by solar power supply.

\section{Methodology}

Refer to Figure 1, the major parts of this program are the soil moisture sensor, controller system design, solar power supply, and sprinkler construction. The main components from the diagram are the controller which consists of analog to digital and digital to analog conversions, the feedback from the soil moisture sensor, rain detector and digital timer with the outputs to activate the valves for both water supply and fertilizing apparatus.

The controller is powered by solar energy which converts the energy into electricity from the photovoltaic cells as the substitute to the direct power supply. The operation of the system is based on the interruption of the voltage differences and resistance changes from the soil moisture sensor. When these occur, the system will execute the decision made and apply according to the rules at appropriate time.

From the block diagram, the first analog response from the soil moisture sensor is transferred to the controller once the sensor detects an interruption signal or voltage drop. Due to this interrupt signal, the controller then started to execute its program which is developed based on the fuzzy logic approach in order to automate the system by activating the valve and turn on the sprinkler based on the rules applied.

The rules developed are based on the weather condition using rain detector in order to indicate the existence of rainfall and digital timer to set the fertilizing time for the plant. The process will go on continuously until the soil moisture sensor sends another signal indicating that there is adequate amount of water in the soil to interrupt the program.

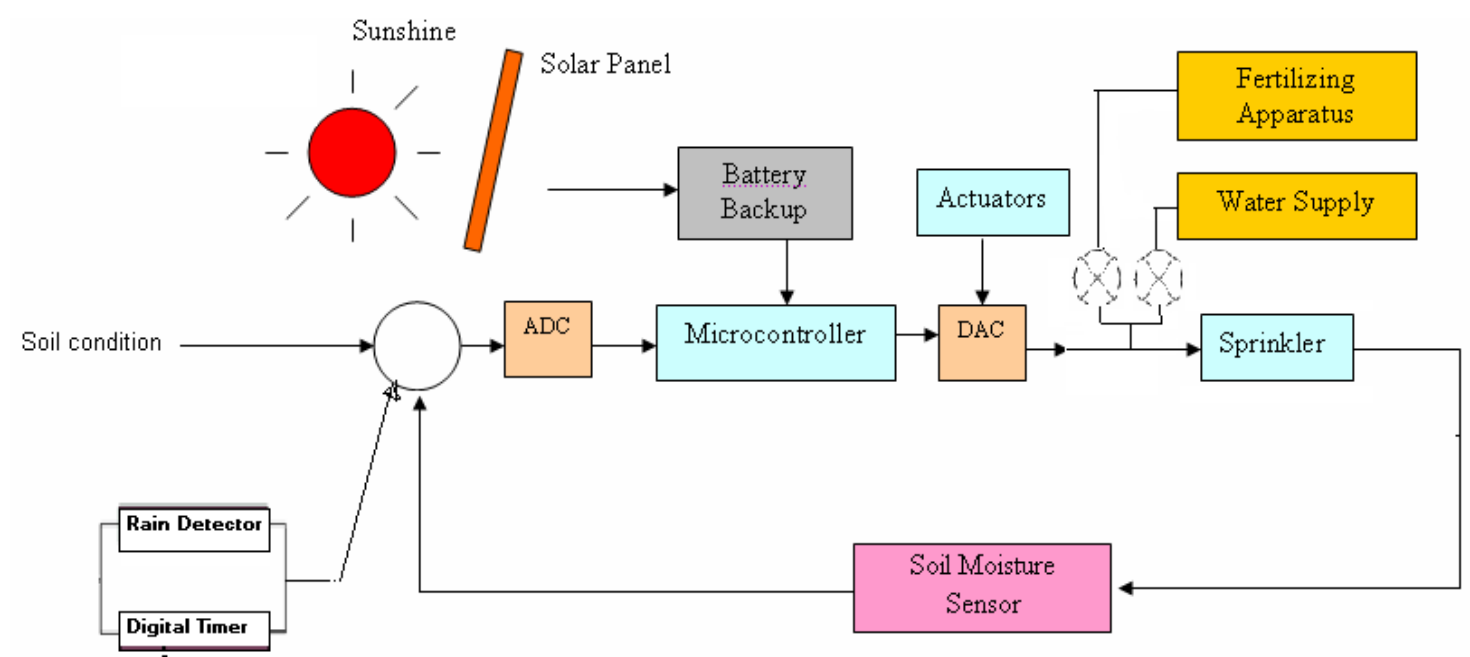

Figure 1. Block diagram of solar-based intelligent water sprinkler. 
In this project, a fuzzy logic approach is implemented by applying set of rules which can operate the system based on weather condition and the needs of fertilization.

Figure 2 shows the mechanism of this water sprinkler. From the starting point, first, the system detected whether all the sensors are in active condition. Then, in the next routine, we measure the soil condition using soil moisture sensor. When there are sufficient amount of water in the soil detected with low voltage input to the microcontroller, the soil wet routine is evaluated. This routine checks the condition according to the fertilizing schedule based on the digital timer. The digital timer is set at 8 a.m in the morning daily for the fertilizing process of the plant. Thus, if timer is alarmed with high voltage signal received by the controller, the valve will activate the sprinkler. Other wise, if

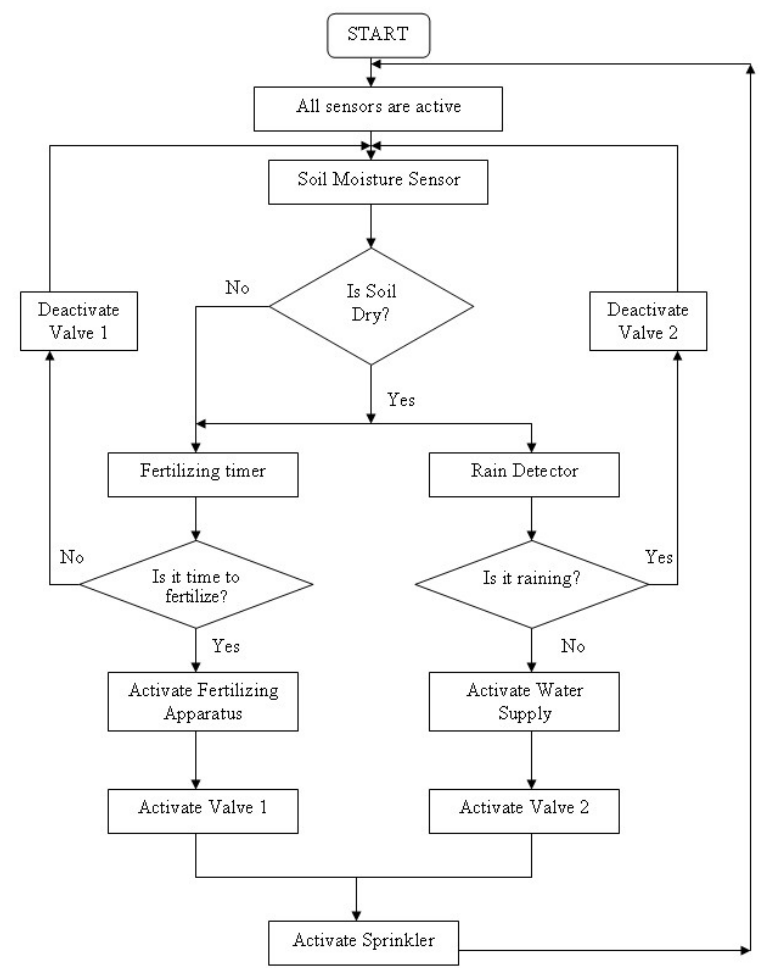

Figure 2. Water sprinkle flowchart. the voltage from the digital timer is low, the valve will not indicate it is no time to fertilize. The duration set to fertilize the plant is one minute.

The next routine is evaluated when the condition for the soil is dry. From here, the controller will first checked the weather condition whether it is raining or not according to the rain detector with rain collector tipping bucket which will be on when it is raining. Then watering the lawn is not necessary when the soil is not dry and the process will loop again to the main program and check the activation of all sensors.

\section{A. Soil Moisture Sensor}

The soil moisture sensor presently being developed measures the change in capacitance across the probe as a function of water content in the surrounding soil. The dielectric constant of water is an order of magnitude greater than that of common soil components. In a soil/water matrix, the amount of water present greatly influences the capacitance between two conductive plates placed in the matrix. The picure of the conceptual circuit is shown in Figure 3. And Figure 4 shows the probe of soil moisture sensor.

The crystal oscillator stabilizes the frequency that is produced by the sensor. There are two

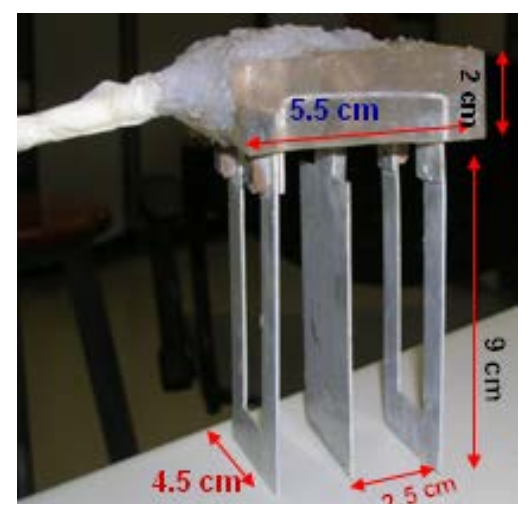

Figure 3. Probe of soil moisture sensor.

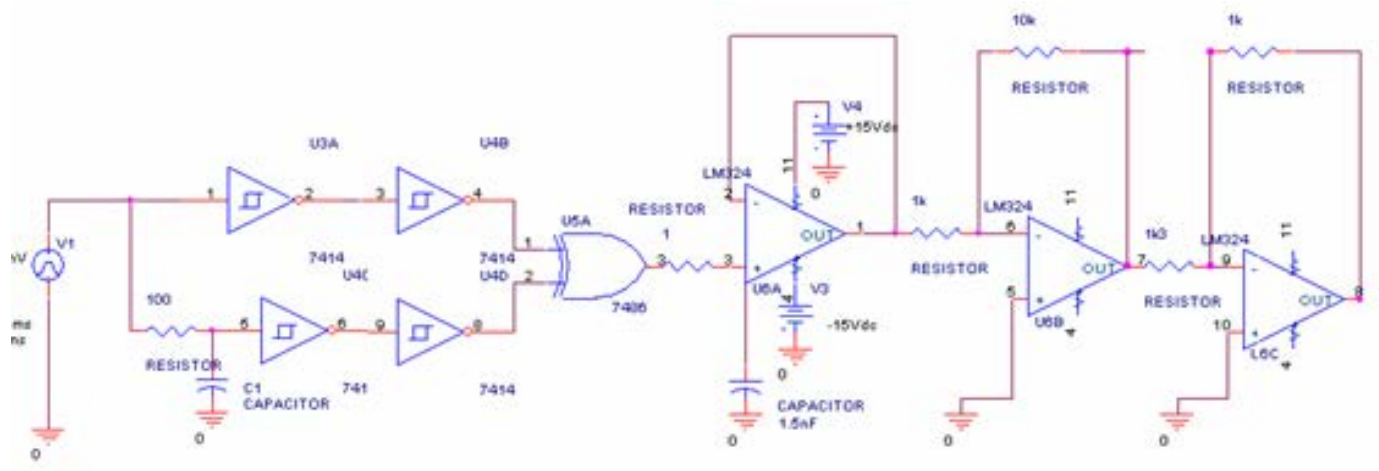

Figure 4. Circuit diagram of soil moisture sensor. 
output produced from the oscillator, where one of the output is inverted. After that, a phase detector compares the frequency produced by the sensor blade (capacitor) with frequency of stable source derived from crystal oscillator. The difference is converted to DC output signal. The phase difference is applied to a filter to get smooth frequency. Amplifier is also used in the sensor system to amplify any small DC signal from the phase detector to a large voltage or a range of voltage that is suitable to the microcontroller. The microcontroller will continuously detect the signal or output from the sensor to activate or deactivate the valves that allow water to flow through to the sprinkler and for watering a certain area.

For example, the output range that is produced by the amplifier (of the sensor) is $0 \mathrm{~V}$ to $5 \mathrm{~V}$. So if the voltage output is $5 \mathrm{~V}$, then the microcontroller will understand that the soil is $100 \%$ dry and needs water. After that, the valve is $\mathrm{ON}$ and the sprinkler waters the area. Because the water sprinkler system is closed loop system, the microcontroller continuously checks the signal from the sensor blade that is placed in the soil. Once the microcontroller detects that the voltage dropped and it tells that the soil is moist enough, the valve is automatically OFF and no water is supplied to the area.

In order to know the suitable voltage range for a few types of soil that will be used in this project, an experiment has been done on those soils. After getting the voltage range, an operational amplifier that can amplify the output of the sensor into a suitable voltage range can be designed.

\section{B. Rain Detector}

A 2" PVC T-connector is used with 4" diameter funnel attached to it. The dual bucket collector is made from aluminum and the water detector probe is used to detect the state of assembly. The cable wire is then attached to the microcontroller and the program is written to increment a counter on every transition (high or low going) of the sensor's output line. The diagram of the rain detector is shown below in Figure 5.

This rain detector was equipped with a circuit as shown in Figure 6. The main component is IC 555 , where the probe will trigger the timer in IC to give high output, using an NPN transistor as an amplifier to gain this signal in order to activate a relay. In normal operation, the relay will be active approximately a second after a signal occurs from the rain detector probe located at the end of the rain collector bucket whenever rain occurs. The relay will remain activated until the signal from the rain detector probe stops or the rain ceases. The output from the relay is measured to be $1.26 \mathrm{~V}$ when the relay is activated. This is insufficient for handy board input, to overcome this, two inverters 74LS04 are placed and the output became $4.67 \mathrm{~V}$ when activated and $1.24 \mathrm{~V}$ when it is deactivated.

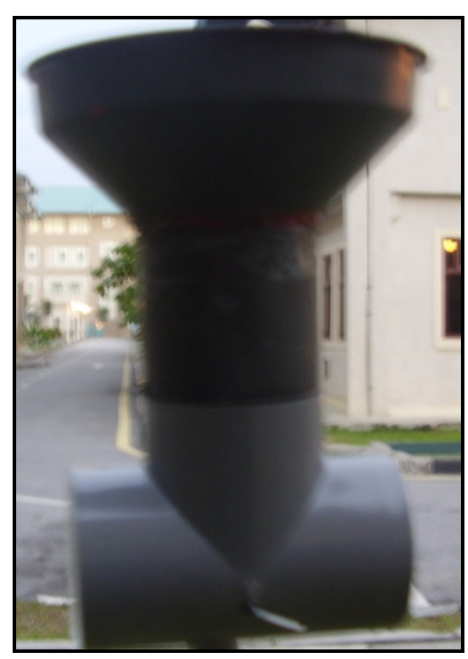

Figure 5. Rain detector.

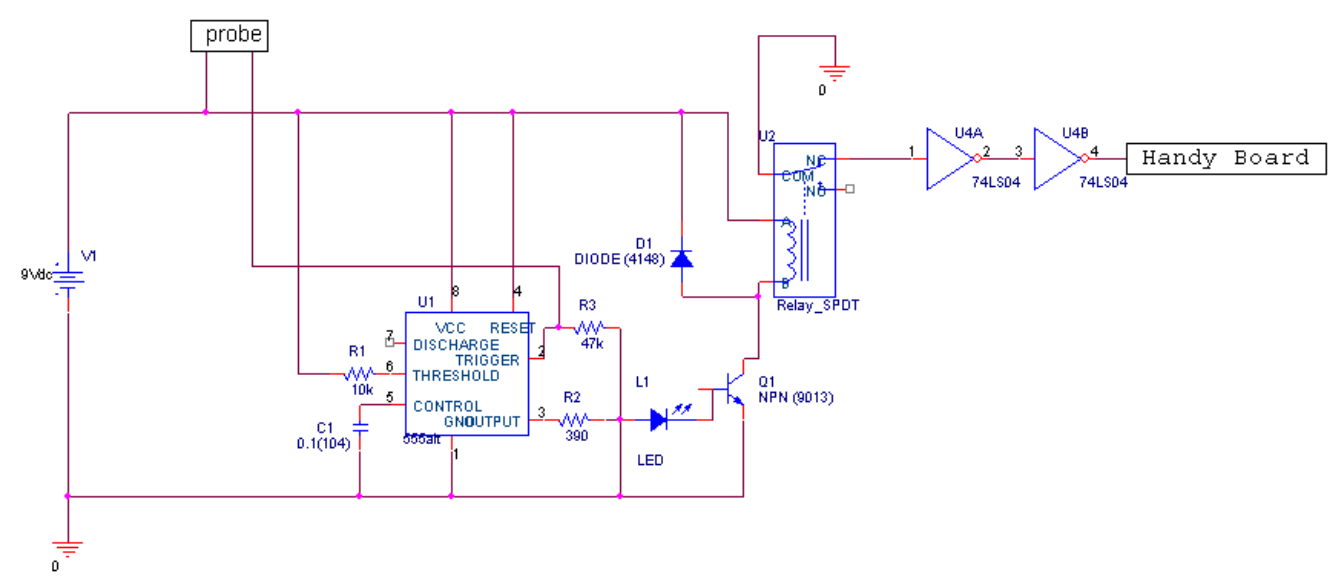

Figure 6. Circuit for rain detector. 


\section{Liquid Fertilizer}

Liquid or water soluble fertilizer are easy to use with the irrigation sprinkler, and like all liquid or water soluble fertilizers, the risk of burning the lawn and plants can be avoided. Liquid and water soluble fertilizers are ideal for deep root feeding of shrubs, trees, landscape ornamentals and lawns. It is also easy to apply fertilizer directly to the leaf surface. Not only do liquid or water soluble fertilizers immediately feed leaves and roots, but by using liquids harmful runoff can also be avoided.

The conceptual design of the fertilizing apparatus is sketched in Figure 7. This apparatus gives a continuous addition of a selected amount of fertilizer. The system splits incoming water into the dispenser and underneath the dispenser where a steel washer with an inward faced beveled through-hole along with the cap forms a point of lowest pressure region where the fertilizer is injected into an output fluid flow to the sprinkler and dependent upon different sizes of the cap.

\section{Fuzzy Mechanism}

This controller for water sprinkle system is designed by implementing an intelligent system where the controller will execute its program based on the signal sends from the sensor and makes decision by the rules set based on the weather condition and fertilizing time for the plant. The input of the controller is in the form of voltage drop and the change of resistance in the soil.
The set of rules for fuzzy logic approach is as below.

Input Membership Function

$$
\begin{aligned}
& \text { Soil_dry } \\
& \text { Soil_wet } \\
& \text { Yes_Fert } \\
& \text { No_Fert } \\
& \text { Rainy } \\
& \text { No_rain }
\end{aligned}
$$

Output Membership Function

Valve1_oN ( Fertilizing apparatus )

Valve1_0FF

Valve2_ON ( Water supply )

Valve2_OFF

Valve1 = Fertilizing apparatus

Valve2 = Water supply

Rules of the Membership Function are as below:

1. IF Soil_dry, Yes_Fert AND Rainy THEN Valve1_ON, Valve2_OFF

2. IF Soil_dry, Yes_Fert AND No_rain THEN Valve1_ON, Valve2 ON

3. IF Soil_dry, No_Fert AND Rainy THEN Valve1_OFF, Valve2_OFF

4. IF Soil_dry, No_Fert AND No_rain THEN Valve1_OFF, Valve2_ON

5. IF Soil_wet, Yes_Fert THEN Valve1_0N, Valve2_OFF

6. IF Soil_wet, No_Fert THEN Valve1_OFF, Valve2_OFF

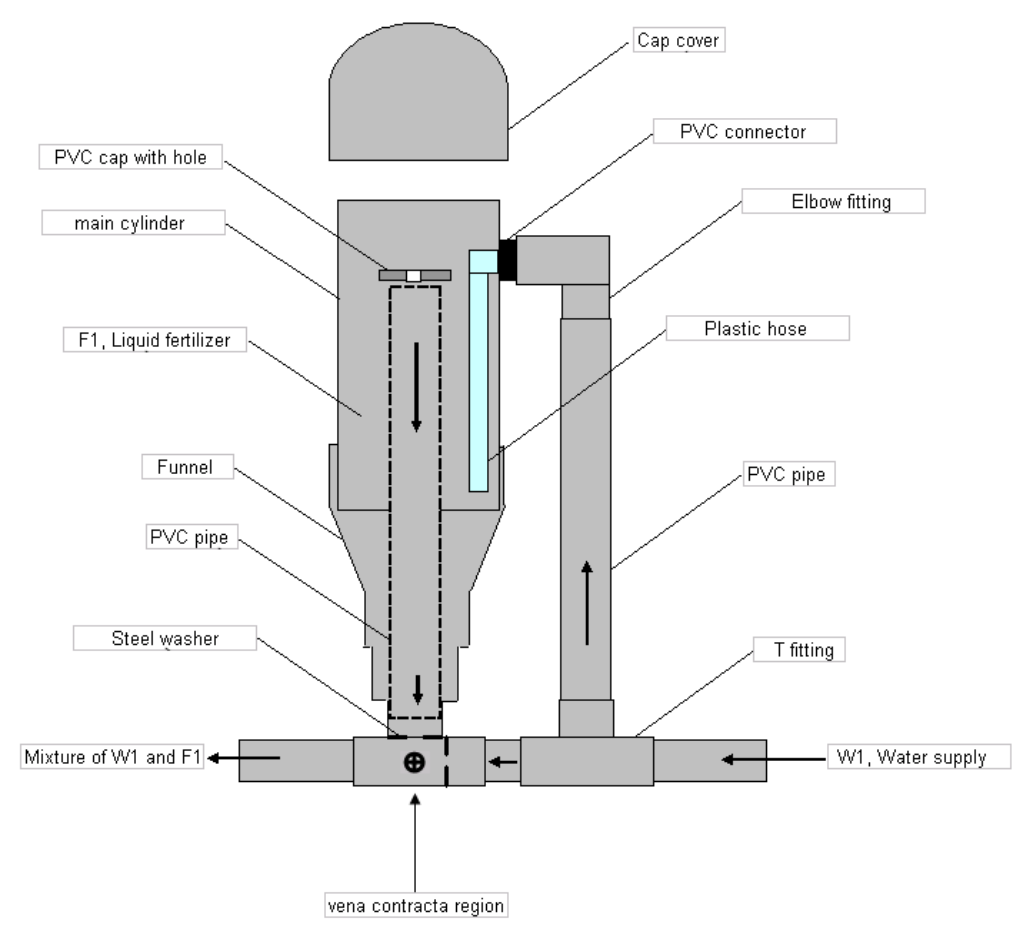

Figure 7. Fertilizing apparatus. 


\section{RESULTS}

Figure 8 and 9 show the experimental results for a day data in range of time from 7:15 am to 7:00 pm The data is collected by elapsed time within 15 minutes.

The data was collected based on the input and output of the controller. There are three inputs of the controller which are soil moisture sensor, rain detector and fertilizing timer. While the outputs are the $6 \mathrm{~V}$ relay controlling the solenoid valves for both the water supply and the fertilizing apparatus. Based on Figure 8 and 9, when this system worked from 07:00 am, the fertilizing apparatus worked to supply the liquid fertilizes at 08:00 am.
The soil moisture sensor always detects the soil condition. At 01:00 pm, when the values of moisture sensor dropped, water valve was ON to supply the water. The rain sensor detected the rain condition at 03:00 - 04:30 pm.

From the experiment, the output measured from the soil moisture sensor at dry condition was between $1.96 \mathrm{~V}$ to $2.94 \mathrm{~V}$. It can be concluded from the graph that more water can be saved if the system can work automatically. The healthy growth of the plant is taken care by the needs of its nutrient as we set the time to fertilize daily and the soil moisture content for different area is measured and over watering will not occur at rain condition.

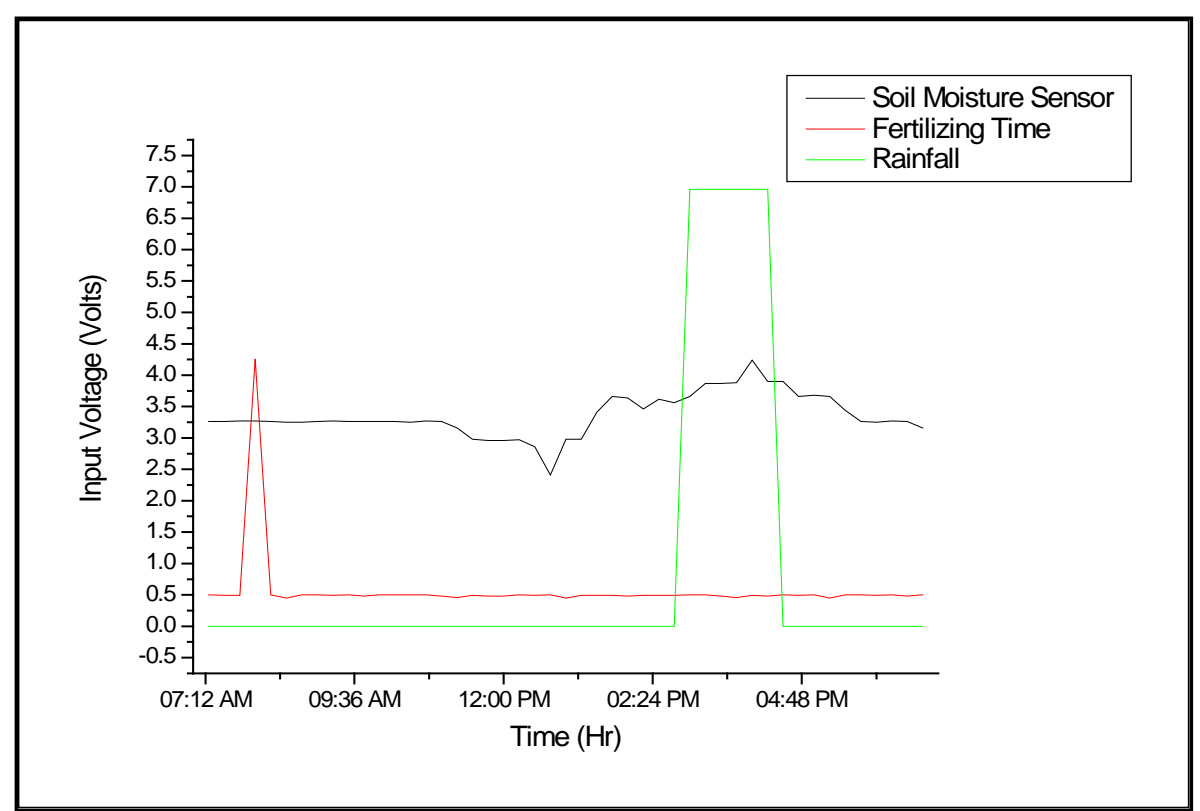

Figure 8. Performance of soil moisture sensor, fertilizing drop and rain sensor.

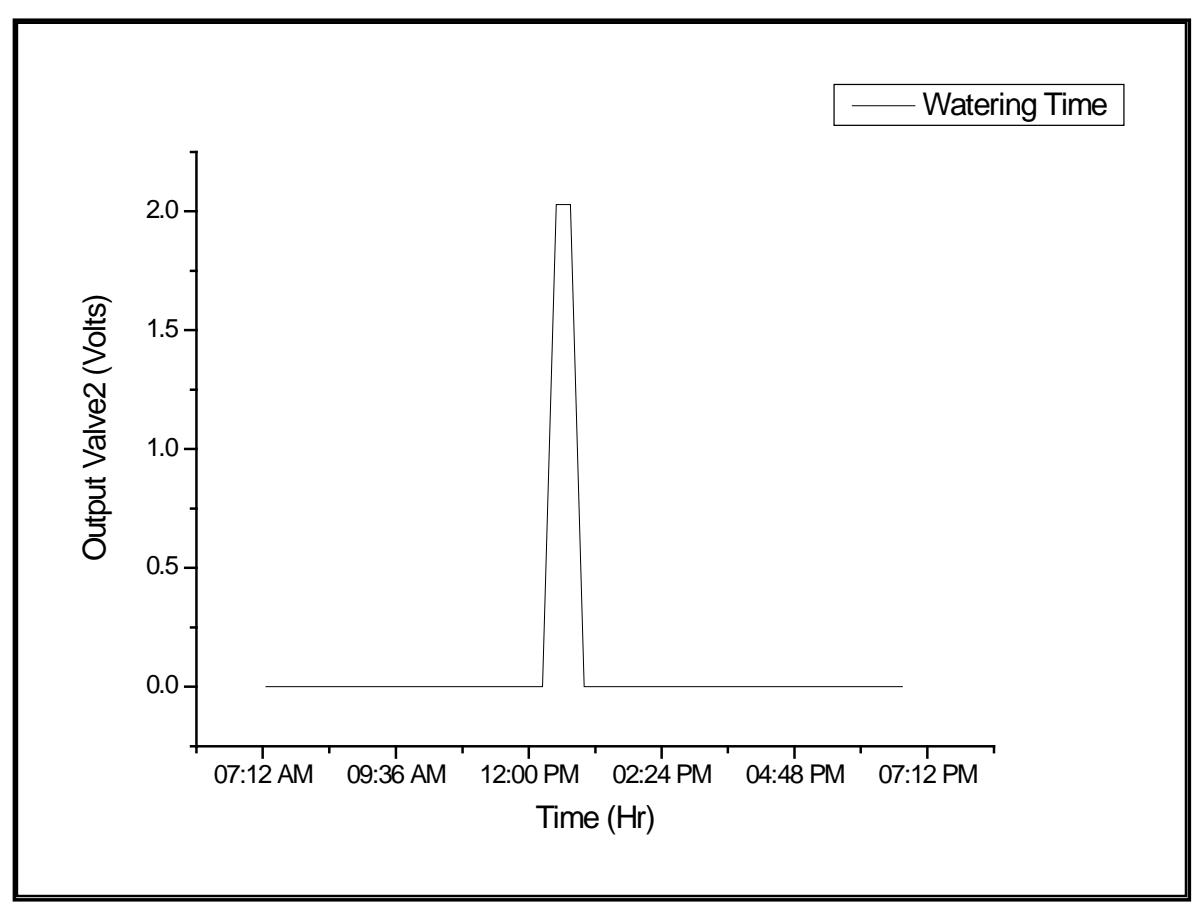

Figure 9. Performance of sprinkle watering system. 


\section{CONCLUSions}

Through this work, we implemented the intelligent system for irrigation and water distribution to make it more efficient to safe water and energy.

The overall design of the controller and its system integration on both hardware and software are expected to be realistic and the whole operation meets its objectives. In general, the project was a success, with system performing most of the functions as expected.

\section{REFERENCES}

[1] Information Centre of Irrigation and Drainage ICID, 1990.

[2] Kate Ravilious, "A sprinkle of limestone dust makes global warming wishes come true," The New Scientist, Volume 198, Issue 2656, p. 16, 17 May 2008.

[3] Saleh M. Ismail, Kiyoshi Ozawa, Nur A. Khondaker, "Influence of single and multiple water application timings on yield and water use efficiency in tomato (var. First power)," Agricultural Water Management, Volume 95, Issue 2, pp. 116-122, February 2008.

[4] Mahdi Gheysari, Seyed Majid Mirlatifi, Mohammad Bannayan, Mehdi Homaee, Gerrit Hoogenboom, "Interaction of water and nitrogen on maize grown for silage," Agricultural Water Management, Volume 96, Issue 5, pp. 809-821, May 2009.

[5] Yaohu Kang, Ming Chen, Shuqin Wan, "Effects of drip irrigation with saline water on waxy maize (Zea mays L. var. ceratina Kulesh) in North China Plain," Agricultural Water Management, Volume 97, Issue 9, pp. 1303-1309, September 2010.

[6] Ming Chen, Yaohu Kang, Shuqin Wan, Shiping Liu, "Drip irrigation with saline water for oleic sunflower (Helianthus annuus L.)," Agricultural Water Management, Volume 96, Issue 12, pp. 1766-1772, December 2009.

[7] Öner Çetin, Demet Uygan, "The effect of drip line spacing, irrigation regimes and planting geometries of tomato on yield, irrigation water use efficiency and net return," Agricultural Water Management, Volume 95, Issue 8, pp. 949-958, August 2008.

[8] Salah E. El-Hendawy, Essam A. Abd ElLattief, Mohamed S. Ahmed, Urs Schmidhalter, "Irrigation rate and plant density effects on yield and water use efficiency of drip-irrigated corn,"
Agricultural Water Management, Volume 95, Issue 7, pp. 836-844, July 2008.

[9] Xi Liang, Derong Su, Shuxia Yin, Zhi Wang, "Leaf water absorption and desorption functions for three turfgrasses," Journal of Hydrology, Volume 376, Issue 12, pp. 243-248, 30 September 2009.

[10] D. Isidoro, D. Quílez, R. Aragüés, "Drainage water quality and end-member identification in La Violada irrigation district (Spain)," Journal of Hydrology, Volume 382, Issue 14, pp. 154-162, 1 March 2010.

[11] J.N. Ortíz, J.A. de Juan, J.M. Tarjuelo, "Analysis of water application uniformity from a centre pivot irrigator and its effect on sugar beet (Beta vulgaris L.) yield," Biosystems Engineering, Volume 105, Issue 3, pp. 367-379, March 2010.

[12] R. Delirhasannia, A.A. Sadraddini, A.H. Nazemi, D. Farsadizadeh, E. Playán, "Dynamic model for water application using centre pivot irrigation," Biosystems Engineering, Volume 105, Issue 4, pp. 476485, April 2010.

[13] Hong Li, Tingxian Li, Robert J. Gordon, Samuel K. Asiedu, Kelin Hu, "Strawberry plant fruiting efficiency and its correlation with solar irradiance, temperature and reflectance water index variation," Environmental and Experimental Botany, Volume 68, Issue 2, pp. 165-174, April 2010.

[14] CS 411 ILCS, Intelligent Lawn Care System (Spring 2003). Virginia: Old Dominion University, [online] Available: http://www.coursehero.com/file/3285859/IL CS/ [accessed: November 20, 2011]

[15] Aaron Wills, (October 25, 2002), "Development and Test of Sensor-Aided Microcontroller based Irrigation System with Web Browser Interface," Perth, WA: Dept of Electrical and Computer Engineering Curtin University pp. 5-6,. [online] Available: http://www.jkmicro.com/irrigation_thesis.pd f, [accessed: November 20, 2011]

[16] Mohd Taufiq B, Mohd Yusof, Designing and Prototyping of Automatic Garden Watering System. Kuala Lumpur, Malaysia: International Islamic University Malaysia, 2005.

[17] Brent Q Mercham, (Apr 2010), Using Soil Moisture Sensors to Control Landscape Irrigation. Loveland, Colorado: Northem Colorado Water Conservancy District Loveland, [online] Available: http://www.docstoc.com/docs/33299632/Usi 
ng-Soil-Moisture-Sensors-to-Control-

Landscape-Irrigation [accessed: November 20, 2011]

[18] Richard R. Spencer \& Mohammed S. Ghausi, Introduction to Electronic Circuit Design. 1st ed, New Jersey: Prentice Hall, August, 2002. 